\title{
Propofol Induced Anaphylaxis, A Rare Anaesthetic Emergency: A Case Report
}

\author{
Bhawna Saini ${ }^{1 *}$, Arkapal Bandyopadhyay ${ }^{1}$, Mohit Kumar ${ }^{2}$, Sameer Mohan Agarwal ${ }^{2}$, Sandeep Saini ${ }^{3}$ \\ ${ }^{1}$ Department of Pharmacology, AIIMS, Rishikesh, Uttarakhand, India. \\ ${ }^{2}$ Department of Anaesthesia, AlIMS, Rishikesh, Uttarakhand, India. \\ ${ }^{3}$ Department of Nephrology, AIIMS, Rishikesh, Uttarakhand, India. \\ *Corresponding author's E-mail: bhanu.gsvm@gmail.com
}

Received: 12-07-2020; Revised: 24-08-2020; Accepted: 30-08-2020.

DOI: $10.47583 /$ ijpsrr.2020.v64i01.035 \begin{abstract}
Anaphylaxis is a serious side effect experienced by mainly anaesthetists as compare to other physicians. Owing to simultaneous administration of many drugs in perioperative period, causality assessment of drug causing the adverse reactions is usually difficult. Here, were present a rare case of a propofol induced hypersensitivity reaction in a young lady who was posted for a robotic cystectomy under general anaesthesia for ovarian cyst. She was given Propofol in perioperative period along with other anaesthetics. She developed hypotension, tachycardia and facial flushing, angioedema and urticaria over forearms. The causal agent of this adverse event was confirmed by measurement of mast cell tryptase, multiple skin patch test and intradermal sensitivity test. Patch and intradermal sensitivity test were negative for all the drugs used in perioperative period except propofol. Clinical features, investigation and causality assessment suggest Propofol to be the causative drug for anaphylactic reaction. All patients with a suspected anaphylactic reaction during anaesthesia should be investigated to determine the allergic nature of the reaction and to identify the responsible drug.
\end{abstract}

Keywords: Anaphylaxis, Causality assessment, Propofol.

\section{INTRODUCTION}

A naphylaxis is an acute life threatening systemic hypersensitivity reaction. The most common system affected in anaphylactic reaction includes cardiovascular system (tachycardia, hypotension, arrhythmia, myocardial depression, cardiovascular collapse), followed by cutaneous symptoms (flushing and urticaria) and respiratory (bronchoconstriction and laryngeal oedema) symptoms. Any delay in early detection and proper management of anaphylaxis can be fatal. Perioperative anaphylaxis incidence during anaesthesia ranges from 1:5000 to $1: 25000$ with $3.4 \%$ mortality rate. ${ }^{1}$ Almost all the drugs administered perioperatively may lead to anaphylactic reactions.

The most common triggers for anaphylaxis during perioperative period are neuromuscular blocking drugs (NMBDs), latex and antibiotics. ${ }^{2}$ Other drugs like sedatives, local anaesthetics and opioids rarely cause anaphylaxis. Propofol anaphylaxis attribute to $1.2 \%$ cases of perioperative anaphylactic shock. ${ }^{3}$ Although, incidence rate of Propofol induced anaphylaxis is low but anaphylaxis creates an emergency situation in operation theatre. Drugs causing anaphylaxis in perioperative period are listed in Table-1.
Table 1: Drugs causing anaphylaxis during perioperative events ${ }^{4}$

\begin{tabular}{|l|l|l|}
$\begin{array}{l}\text { S. } \\
\text { no. }\end{array}$ & Drugs causing anaphylaxis & $\begin{array}{l}\text { Incidence } \\
\text { (\%) }\end{array}$ \\
\hline 1. & $\begin{array}{l}\text { NMBDs, most commonly } \\
\text { Rocuronium and Succinylcholine }\end{array}$ & $58.2 \%$ \\
\hline 2. & Latex & $16.7 \%$ \\
\hline 3. & Antibiotics & $15.1 \%$ \\
\hline 4. & Colloids & $4.0 \%$ \\
\hline 5. & Hypnotics & $3.4 \%$ \\
\hline 6. & Propofol & $1.2 \%$ \\
\hline
\end{tabular}

\section{CASE HISTORY}

A 26-years old lady presented with abdominal pain for 6 months. She was diagnosed with endometriosis and ovarian cyst for which robotic cystectomy was planned under general anaesthesia. She didn't have any documented history of food and drug allergies. Baseline pre-anaesthetic investigations like complete blood count, liver function test, kidney function test, chest X-ray, echocardiography was within normal limits. Pre-induction medications were administered half an hour before arriving into operation theatre. Injection Midazolam $2 \mathrm{mg}$ and injection Glycopyrrolate $0.2 \mathrm{mg}$ were given intramuscularly. The baseline readings of vitals (Blood pressure118/74 $\mathrm{mm} \mathrm{Hg}$, pulse rate $76 / \mathrm{min}$ and oxygen saturation $99 \%$ ) were noted in operation theatre. 
General anaesthesia with Fentanyl citrate (100 $\mu \mathrm{g}$ iv), Propofol (120 mg iv) with $40 \mathrm{mg}$ lignocaine $2 \%$ were injected intravenously with $100 \%$ oxygen @3litre/min and Sevoflurane @ 3\%. When patient lost her consciousness, she was put on ventilation by endotracheal intubation after 3 minutes of injecting intravenous Vecuronium bromide $(6 \mathrm{mg})$. Patient was positioned in lithotomy to start the operative procedure. With-in 10 minutes of induction, her heart rate started increasing to $140 / \mathrm{min}$ and blood pressure dropped to $78 / 34 \mathrm{~mm} \mathrm{Hg}$. Effect of anaesthetic agent was suspected as a cause of adverse event, so anaesthetic medication was discontinued and injection Mephentermine $6 \mathrm{mg}$ was given. Blood pressure reading after $3 \mathrm{~min}$ was $64 / 32 \mathrm{~mm} \mathrm{Hg}$ with heart rate $166 /$ min. Patient began to develop facial flushing, angioedema and urticaria over forearms.

Patient was diagnosed as a case of anaphylaxis. Immediate resuscitation was done with injection Adrenaline $300 \mu \mathrm{g}$ subcutaneously along with administration of fluid rush. Injection Hydrocortisone 200mg, injection Dexamethasone $8 \mathrm{mg}$, injection Chlorpheniramine maleate $20 \mathrm{mg}$ was given via intravenous route. Vasopressor support was started with Noradrenaline single strength infusion at $10 \mu \mathrm{g} / \mathrm{min}$. Vitals were monitored every 10 minutes. Her vital signs recovered within 20 minutes with blood pressure and pulse rate 110/66 mm Hg and 90/min respectively. Facial flushing, angioedema and urticaria persisted. Patient was shifted to ICU for further management by surgical and anaesthesia team. Within 24 hour of ventilators support and intravenous steroids administration, oedema, flushing and urticaria had subsided.

Blood sample was taken immediately for measurement of mast cell tryptase levels to confirm anaphylactic reaction. Tryptase level was reported 15.6. Multiple skin patch test and intradermal sensitivity test were performed so as to evaluate the etiology retrospectively. Patch and intradermal sensitivity test were negative for all the drugs used in perioperative period except propofol. Propofol was suspected to be the causative drug.

After performing leak test patient was extubated and kept under observation. The surgery was postponed to a later date. The patient was kept under observation for $24 \mathrm{~h}$ in the post-anaesthesia care unit and discharged after 48 hours of the event.

\section{Adverse drug reaction assessment tools-}

Causality assessment of the adverse drug reaction was Probable as per Naranjo scale and WHO-UMC causality scales. Severity of ADR was severe (level-5) as per Hartwig's severity assessment scale. Preventability was established by Modified Shummock and Thornton scale that revealed non-preventable $A D R .^{5}$ The compiled analysis of ADR is available in Table- 2 .
Table 2: Analysis of the ADR

\begin{tabular}{|c|c|c|}
\hline \multicolumn{2}{|l|}{ Types } & Propofol \\
\hline \multirow[t]{2}{*}{ Causality } & Naranjo Scale & Probable \\
\hline & WHO-UMC Scale & Probable \\
\hline Severity & $\begin{array}{l}\text { Hartwig's severity } \\
\text { assessment scale }\end{array}$ & Severe \\
\hline Preventability & $\begin{array}{l}\text { Modified } \\
\text { Shummock and } \\
\text { Thornton Scale }\end{array}$ & Notpreventable \\
\hline
\end{tabular}

\section{DISCUSSION}

Pre-anaesthetic medication induced anaphylaxis is difficult to evaluate owing to multiple drug exposure in a short span of time. Basic pathophysiology of drug induced anaphylaxis starts with the binding of an allergen to IgE on the surface of mast cells and basophils leading to massive release of allergic mediators like histamine, leukotriene, kinins, and eosinophil. The patient presents with severe bronchoconstriction, vasodilatation and increased capillary permeability. ${ }^{6}$

Propofol (2, 6 di-isopropyl phenol) is available in market as a lipid vehicle containing soya bean oil, egg lecithin and glycerol. Propofol has two potential allergenic molecules di-isopropyl side chain and phenol. Allergic reactions to Propofol on first exposure are usually due to isopropyl group that may act as epitopes. Isopropyl group is present in several cosmetics products and medicines. Allergic reactions to Propofol upon re-exposure are usually due to the Phenol moiety. Propofol is not contraindicated in patients who are allergic to egg or soya. ${ }^{7}$

\section{CONCLUSION}

Our suspicion of anaphylaxis was based on the presence of severe hypotension, tachycardia and cutaneous rashes all over the body. A suspicion of Propofol induced anaphylactic reaction was confirmed by measurement of mast cell tryptase levels, multiple skin patch test and intradermal sensitivity test. Our finding is supported by published case reports of propofol induced adverse drug reactions like study done by Laxenaire et $\mathrm{al}^{8}$, Koul, et $\mathrm{al}^{9}$ and Mota et al. ${ }^{10}$

\section{REFERENCES}

1. Mertes PM, Laxenaire MC. Allergic reactions occurring during anaesthesia. Eur J Anaesthesiol, 19(4), 2002 Apr, 240-62. DOI: 10.1017/s0265021502000418. PMID: 12074414

2. Laxenaire MC, Mertes PM. Anaphylaxis during anesthesia. Results of a two-year survey in France. $\mathrm{Br}$ J Anaesth, 87(4), 2001, 549-58. DOI: 10.1093/bja/87.4.549. PMID: 11878723

3. Gangineni K, Scase AE, Fearn J. Propofol and peanut allergy. Anesthesia, 62, 2007, 1191. DOI: 10.1111/j.1365-2044.2007.05337.x 
4. Tomar GS, Tiwari AK, Chawla S, MukherjeeA, Ganguly S. Anaphylaxis related to fentanyl citrate. J Emerg Trauma Shock, 5(3), 2012, 257-61. DOI: 10.4103/0974-2700.99703

5. Saini B, Kumar M,Bandyopadhyay A. Topical corticosteroids inducedhyper-pigmentation: a case report. Int J Res Dermatol, 5, 2019, 889-93. DOI: 10.18203/issn.2455-4529

6. Roizen MF, Fleisher LA. Anesthetic implications of concurrent diseases. In: Miller RD, editor. Anesthesia. 6th ed. Philadelphia: Elsevier; 2005. p. 1092-3

7. L'Hocine L, Boye Jl. Allergenicity of soybean: new developments in identification of allergenic proteins, cross-reactivities and hypoallergenization technologies. Crit Rev Food Sci Nutr, 47, 2007, 127-43. DOI: 10.1080/10408390600626487. PMID: 17364698

8. Laxenaire MC, Bermejo E, Vautrin D, Gueant JL. Life threatening anaphylactoid reactions to propofol (Diprivan ${ }^{\circledR}$ ). Anesthesiology 77, 1992, 275-80. DOI: 10.1097/00000542-199208000-00009.

PMID: 1379418

9. Koul A, Jain R, Sood J. A critical incident report: Propofol triggered anaphylaxis. Indian J Anaesth, 55, 2011, 530-3. DOI: 10.4103/0019-5049.89898. PMID: 22174476

10. Mota AC, Pereira F, Guimaraes J, Neves E, Sa P. Propofol Induced Anaphylaxis-A Case Report. J Allergy Ther. 6(209), 2015, 2. DOI: 10.4172/21556121.1000209

Source of Support: None declared.

For any question relates to this article, please reach us at: editor@globalresearchonline.net

New manuscripts for publication can be submitted at: submit@globalresearchonline.net and submit_ijpsrr@rediffmail.com 